\title{
Análise da textura de peitos de frangos alimentados com ração contendo ácidos orgânicos ou antibiótico
}

\author{
Pascoal Funari Junior \\ Adriele Nayara Dias Ishizuka \\ Lígia Grisólia do Carmo \\ Aline de Oliveira Rodrigues \\ Rayane Sol Amaral Silva \\ Fabrício Singaretti de Oliveira* \\ Departamento de Medicina Veterinária, Universidade Estadual de Maringá, Campus Umuarama \\ Caixa Postal 65, CEP 87501-970, Umuarama - PR, Brasil \\ *Autor para correspondência \\ singaretti@ig.com.br
}

Submetido em 27/02/2011

Aceito para publicação em 30/09/2011

\section{Resumo}

Este trabalho teve como objetivo analisar a textura de músculos peitorais de frangos de 42 dias submetidos a três tratamentos com a ração (grupo controle, sem aditivos; grupo com adição de uma mistura de ácidos orgânicos livres; e grupo com adição de antibiótico promotor de crescimento). O delineamento experimental foi o inteiramente ao acaso e cada tratamento teve quatro repetições de 12 aves. Para a análise da textura, foram escolhidos dois peitos de frango por repetição, que foram cortados e cozidos. Em seguida, quatro amostras de cada peito de frango foram coletadas para avaliar a força de cisalhamento. A força de cisalhamento do grupo controle apresentou a menor média (18,93kgf), a do tratamento com a mistura de ácidos orgânicos livres foi de $19,46 \mathrm{kgf}$, e a do tratamento com antibiótico, 18,94kgf. Não houve diferença significativa $(\mathrm{P}>0,05)$ entre os grupos, indicando que a adição de ácidos orgânicos livres ou antibióticos promotores de crescimento na alimentação de frangos de corte não interferiram na força de cisalhamento da textura da carne do peito desses animais.

Palavras-chave: Ácidos orgânicos, Aves, Textura

\section{Abstract}

Analysis of breast texture on chicken fed with organic acids or antibiotic in food. This work aimed to analyze the texture of 42-day-old chicken breast muscles which underwent three treatments with the food (control group, with no additives; group with addition of a free organic acids mixture; and group with addition of growth-promoting antibiotic). The experiment had a random design and each treatment presented four repetitions of 12 chickens. For the texture analysis, two chicken breasts were chosen in each repetition, which were cut and cooked. Subsequently, four samples of each chicken breast were collected to measure the shear force. The shear force of the control group presented the lowest mean value $(18.93 \mathrm{kgf})$, the mean value from the free organic acids treatment was $19.46 \mathrm{kgf}$, and the mean value from the antibiotics treatment was $18.94 \mathrm{kgf}$. There was no significant difference $(\mathrm{P}>0.05)$ between groups, indicating that adding free organic acids or growth-promoting antibiotics in the food of chickens did not influence the shear force of the breast meat texture of these animals.

Key words: Organic acids, Poultry, Texture 


\section{Introdução}

A maciez ou textura de um músculo pode ser avaliada mediante um analisador de textura ou texturômetro (CULIOLI, 1995), o qual mensura a força necessária para que uma lâmina rompa as fibras musculares de um fragmento (força de cisalhamento FC). O resultado é expresso em quilograma-força (kgf) (BOURNE, 1982; SOUZA, 2008) e mensura um dos principais atributos de qualidade da carne (FLETCHER, 2002), a qual pode se determinada por fatores como alimentação (MONSÓN et al., 2005), idade, estresse, entre outros (VENTURINI et al., 2007).

Este trabalho objetivou descrever se ração contendo ácidos orgânicos ou antibiótico interfere na textura de peitos de frangos, a qual é um dos parâmetros utilizados para avaliação da maciez da carne.

\section{Materiais e Métodos}

O experimento foi conduzido em frangos de 1 a 42 dias de idade, machos, da linhagem Cobb. Durante todo o período experimental, as aves receberam água e ração ad libitum. As rações foram isoprotéicas e isocalóricas, a base de milho e soja, e a formulação obedeceu aos níveis nutricionais recomendados por Rostagno et al. (2005).

O delineamento experimental foi o inteiramente casualizado, com três tratamentos de quatro repetições cada: 1 - Controle sem aditivos; 2 - Com a adição de uma mistura de ácidos orgânicos livres (Ac. láctico $9 \%$, propiônico $15 \%$ e fórmico $23,5 \%$ - 3kg/ton); 3 Com a adição de antibiótico promotor de crescimento (bacitracina de zinco $11 \%$ - 50ppm/ton).

Foram escolhidos dois peitos de frango de cada repetição, totalizando oito peitos em cada tratamento. Após serem cortados, os peitos foram envolvidos em papel alumínio e cozidos a $75^{\circ} \mathrm{C}$ e, em seguida, foram devidamente secos.

Foram retiradas quatro amostras de cada músculo peitoral maior ( $M$. pectoralis major), na forma de paralelepípedo, com aproximadamente $2 \mathrm{~cm}$ de comprimento, largura e altura, as quais foram colocadas com as fibras orientadas no sentido perpendicular à lâmina do texturômetro (FRONING et al., 1978) (Warner-Bratzler TAZT2i ${ }^{\circledR}$ ), pertencente ao Laboratório de Alimentos do Departamento de Medicina Veterinária da UEM - Campus Umuarama, PR. A FC foi medida em cada amostra.

Os dados foram submetidos à análise de variância e as médias comparadas pelo teste de Tukey $(\mathrm{P}<0,05)$, por meio do aplicativo Statgraphics ${ }^{\circledR}$.

\section{Resultados e Discussão}

A FC do grupo controle apresentou a menor média $(18,93 \mathrm{kgf})$, a do tratamento com a mistura de ácidos orgânicos livres foi de $19,46 \mathrm{kgf}$, e a do tratamento com antibiótico, 18,94kgf. Não houve diferença significativa $(\mathrm{P}>0,05)$ entre os grupos, indicando que a adição de ácidos orgânicos livres ou antibióticos promotores de crescimento na alimentação de frangos de corte não interferiram na FC da textura da carne do peito destes animais, similarmente ao observado por Murakami et al. (2008), que avaliaram a textura da carne de frangos submetidos à dieta com ácidos graxos poliinsaturados. Embora estes autores tenham observado médias menores de FC associadas ao consumo dos ácidos graxos, não houve diferença estatística entre os grupos.

Ainda, nossos resultados são similares aos de Duarte et al. (2007), os quais reportaram não haver alterações significativas quanto à $\mathrm{FC}$ em peitos de frangos submetidos a diferentes níveis de energia e programas de alimentação sobre a qualidade de carcaça.

A partir dos resultados é possível concluir que as adições de ácidos orgânicos livres ou antibióticos promotores de crescimento na ração não foram capazes de expressar diferenças significativas na textura da carne do peito de frango.

\section{Referências}

BOURNE, M. C. Principles of objective texture measurement. In: BOURNE, M. C. (Ed.). Food texture and viscosity: concept and measurement. New York: Academic Press, 1982. p. 114-117.

CULIOLI, J. Meat tenderness: mechanical assessment. In: OUALI, A.; DEMEYER, D. I.; SMULDERS, F. J. M. (Ed.). Expression of tissue proteinases and regulation of protein degradation as 
related to meat quality. The Netherlands: Ecceamst, 1995. p. 239263.

DUARTE, K. F.; JUNQUEIRA, O. M.; FILARDI, R. S.; LAURENTIZ, A. C.; SOUZA, H. B. A.; OLIVEIRA, T. M. F. S. Efeito dos níveis de energia e programas de alimentação sobre a qualidade de carcaça e desempenho de frangos de corte abatidos tardiamente. Acta Scientiarum Animal Science, Maringá, v. 29, p. 39-47, 2007.

FLETCHER, D. L. Poultry meat quality. World's Poultry Science Journal, Ithaca, v. 58, n. 2, p. 131-145, 2002.

FRONING, G. W.; BABJI, A. S.; MATHER, F. B. The effect of preslauther temperature, stress, strugle and anesthetization on color and textural characteristics of turkey muscle. Poultry Science, Savoy, v. 57, n. 3, p. 839-845, 1978.

MONSÓN, F.; SAÑUDO, C.; SIERRA, I. Influence of cattle breed and ageing time on textural meat quality. Meat Science, Illinois, v. 68, p. 595-602, 2004.

MURAKAMI, K. T. T.; RIBEIRO, S. C.; PINTO, M. F. Influência da dieta de frangos de corte sobre a textura e oxidação da carne. Veterinária e Zootecnia, Botucatu, v. 15, n. 2, suplemento 1, p. 121, 2008.
ROSTAGNO, H. S.; ALBINO, L. F. T.; DONZELE, J. L.; GOMES, P. C.; OLIVEIRA, R. F.; LOPES, D. C.; FERREIRA, A. S.; BARRETO, S. L. T. Tabelas brasileiras para aves e suínos: composição de alimentos e exigências nutricionais. Viçosa: Universidade Federal de Viçosa, 2005. 186 p.

SOUZA, P. S. Comparação dos efeitos da temperatura de cocção e espessura da lâmina de corte na força máxima de cisalhamento Warner Bratzler, no Longissimus dorsi e, determinação de um modelo matemático que correlacione estes parâmetros com a força máxima de cisalhamento. PUBVET, Londrina, v. 2, n. 7, sem paginação, 2008.

STATISTICAL GRAPHICS CORPORATION. STATIGRAPHICS plus for Windows 4.1. 1994-1999. CD.

VENTURINI, K. S.; SARCINELLI, M. F.; SILVA, L. C. Características da carne de frango. Vitória: PIE-UFES. 2007. Boletim Técnico. Disponível em: <http://www.agais.com/telomc/ b01307_caracteristicas_carnefrango.pdf $>$. 